\title{
HUBUNGAN TRAVEL CONSTRAIN DAN CITRA DESTINASI TERHADAP LOYALITAS WISATAWAN DI WILAYAH KABUPATEN BOGOR BAGIAN BARAT
}

\author{
RELATIONSHIP OF TRAVEL CONSTRAINTS AND DESTINATION IMAGE ON TOURIST LOYALTY IN \\ THE WESTERN BOGOR REGENCY AREA
}

\author{
Edwin Aldrianto ${ }^{*)}$, Bambang Juanda ${ }^{* *}$, Sri Mulatsih ${ }^{* *}$, Ernan Rustiadi $\left.{ }^{* * *}\right)$ \\ *) PT. Salakadomas Nusantara \\ Jl. Ahmad Sobana 107 Kota Bogor \\ **) Departemen Ilmu Ekonomi, Fakultas Ekonomi dan Manajemen, IPB University \\ Jl. Agatis, Kampus IPB Dramaga, Bogor 16680, Indonesia \\ ${ }^{* * *}$ Departemen Ilmu Tanah dan Sumberdaya Lahan, Fakultas Pertanian, IPB University \\ Jl. Ulin, Kampus IPB Dramaga, Bogor 16680, Indonesia
}

\begin{abstract}
This study aims to analyze the structural relationship between travel constraints and destination image on tourist loyalty. This was conducted in JulyAugust 2019 in Tenjolaya Subdistrict and Pamijahan Subdistrict. The analysis using the PLS SEM method gives the result that the X3 construct (travel constraint) has a significant negative effect (-0.443) in influencing the X8 construct (visitor loyalty) as reflected in the interest in returning visits. This negative value is greater than the structural effect of the X4 construct (sense of place) which is only 0.390. It can be concluded that the destination that only relies on natural conditions has no significant effect on tourists' interest in making return visits if they have traveling constrain to the site.
\end{abstract}

Keywords: destination, rural, tourism, travel constraints

\begin{abstract}
Abstrak: Penelitian bertujuan menganalisis hubungan struktural antara kendala perjalanan dan citra destinasi terhadap loyalitas wisatawan. Ini dilakukan pada bulan Juli-Agustus 2019 di Kecamatan Tenjolaya dan Kecamatan Pamijahan. Analisis menggunakan metode SEM PLS memberikan hasil bahwa Konstruk X3 (travel constrain) berpengaruh negatif secara signifikan $(-0,443)$ dalam memengaruhi konstruk X8 (loyalitas pengunjung) tercermin dari minat kunjungan kembali. Nilai negatif ini lebih besar daripada pengaruh struktural dari konstruk X4 (sense of place), yaitu hanya 0,390 . Hal ini dapat disimpulkan bahwa lokasi yang hanya mengandalkan kondisi alamiah tidak signifikan pengaruhnya terhadap minat wisatawan untuk melakukan kunjungan kembali jika mereka mengalami kendala dalam perjalanan menuju lokasi.
\end{abstract}

Kata kunci: destinasi, desa, wisata, kendala perjalanan, SEM

\footnotetext{
${ }^{1}$ Corresponding author:

Email: edwin25ipb@gmail.com
} 


\section{PENDAHULUAN}

Kabupaten Bogor sampai saat ini menjadi salah satu destinasi wisata pilihan. Hal ini terbukti dengan semakin meningkatnya kunjungan wisatawan ke Kabupaten Bogor selama periode 2013-2016. Pada tahun 2013 terdapat 4.125.260 wisatawan dan tahun 2016 menjadi 8.791.300, atau meningkat sebesar 46,92\%. Data tersebut diperkuat dengan pendapatan PDRB Daerah yang bersumber dari makanan-minuman dan akomodasi yang mencapai Rp4,82 trilyun di tahun 2016 (BPS Kab.Bogor, 2017).

Kabupaten Bogor memiliki banyak tempat wisata yang tersebar namun kunjungan wisatawannya masih belum merata. Hal ini menyebabkan terjadinya perbedaan tingkat perkembangan serta kesenjangan antar wilayah (Tabel 1). Kunjungan wisatawan terpusat di kawasan Puncak (Bogor ke arah Kabupaten Cianjur). Kawasan Puncak memilik banyak keunggulan, selain daya tarik wisatanya yang beragam, juga memiliki akses yang mudah dijangkau serta memiliki fasilitas penunjang yang lengkap dan baik. Saat ini mulai berkembang pula tempat-tempat wisata di kawasan Sentul. Pada umumnya destinasi wisata di kawasan tersebut bercorak mass tourism (wisata massal) dengan daya tarik wisata buatan.

Kondisi yang berbeda dialami oleh destinasi wisata di Kawasan Bogor Bagian Barat (Bogorke arah Kabupaten Lebak), yakni di kawasan desa-desa yang mengarah ke area kaki Gunung Salak-Halimun. Kawasan ini meski memiliki daya tarik alam yang bagus namun masih belum menjadi kawasan utama tujuan wisata bagi para wisatawan yang berasal dari daerah perkotaan sekitar Kabupaten Bogor. Pada umumnya destinasi wisata di kawasan ini bercorak niche tourism (wisata minat khusus) dengan daya tarik wisata alam.

Kunjungan wisata ke Puncak dan sekitarnya pada Tahun 2018 mencapai 4 juta orang yang merupakan $54 \%$ dari total kunjungan wisata ke Bogor. Beberapa tahun ini mulai terlihat perkembangan yang pesat di kawasan Sentul, yang memiliki kunjungan 1,6 juta atau sekitar 22\% (Gambar 1). Sebaran kunjungan wisata dapat dilihat pada Tabel 2, dimana obyek wisata utama yang dikunjungi dapat dilihat pada Tabel 3.

Beberapa pendapat menyatakan bahwa pengembangan wisata perdesaan memberikan dampak pada pengembangan ekonomi wilayah, yakni dengan perannya dalam penyerapan tenaga kerja - mengingat wisata merupakan industri yang paling padat karya (Mitchell dan Hall, 2005), memperkuat koneksi desakota (Schubert, 2006), sebagai pilihan kegiatan ekonomi yang layak oleh orang-orang yang tinggal di perdesaan (Sharpley dan Pearce, 2007), berkembangnya pertanian kecil yang tidak dapat bersaing dengan kondisi yang dipaksakan oleh globalisasi pasar (Ionela, 2015) dan berpeluang menumbuhkan bisnis perdesaan yang berbasis jauh lebih luas (Jepson dan Sharpley, 2015). Di sisi lain Destinasi pedesaan membutuhkan strategi berkelanjutan untuk menghadapi tantangan seperti mempertahankan loyalitas pengunjung (Campon et al. 2017).

Tabel 1. Gambaran perbandingan kawasan wisata Puncak, Sentul dan Bogor bagian barat

\begin{tabular}{|c|c|c|c|}
\hline Aspek & Kawasan Puncak & Kawasan Sentul & Kawasan Bogor Bagian Barat \\
\hline Tingkat Kemajuan & $\begin{array}{l}\text { Sangat berkembang cenderung } \\
\text { over capacity }\end{array}$ & $\begin{array}{l}\text { Baru berkembang, namun } \\
\text { sangat cepat }\end{array}$ & Stagnan \\
\hline $\begin{array}{l}\text { Jenis Atraksi/Daya } \\
\text { Tarik }\end{array}$ & $\begin{array}{l}\text { Alam, Buatan, Modern, variasi } \\
\text { tinggi }\end{array}$ & $\begin{array}{l}\text { Alam, Buatan, Modern, } \\
\text { variasi tinggi }\end{array}$ & Alam, \\
\hline Jenis Pengunjung & Mass Tourist/Nasional/Int & Mass Tourist/Nasional/Int & Niche/Lokal \\
\hline $\begin{array}{l}\text { Kondisi Faktor } \\
\text { Pendukung }\end{array}$ & $\begin{array}{l}\text { Lengkap dan baik, sering } \\
\text { macet, cukup dekat tol } \\
\text { Jagorawi }\end{array}$ & $\begin{array}{l}\text { Lengkap dan baik, relatif } \\
\text { tidak macet, dekat tol } \\
\text { Jagorawi }\end{array}$ & $\begin{array}{l}\text { Kurang lengkap dan kurang baik, } \\
\text { macet, jauh dari Jagorawi }\end{array}$ \\
\hline Investor & $\begin{array}{l}\text { Developer besar, perusahaan } \\
\text { berbagai kelas, perorangan }\end{array}$ & $\begin{array}{l}\text { Developer besar, perusahaan } \\
\text { berbagai kelas, perorangan }\end{array}$ & $\begin{array}{l}\text { Perusahaan kecil, perorangan, } \\
\text { kelompok }\end{array}$ \\
\hline Provider & Profesional & Profesional & Pemula \\
\hline
\end{tabular}




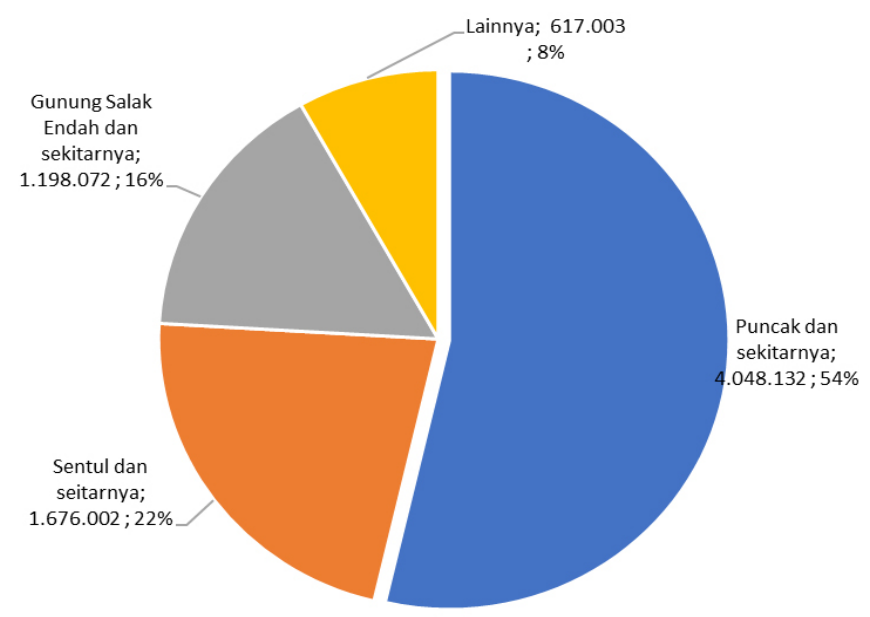

Gambar 1. Komposisi kunjungan wisata menurut kawasan wisata di Kabupeten Bogor tahun 2018 (Dinas Kebudayaan dan Pariwisata Kab. Bogor, 2018)

Tabel 2. $\quad$ Sebaran kawasan wisata, jumlah pengunjung (tahun 2018) dan wilayah Kecamatan

\begin{tabular}{|c|c|c|c|c|}
\hline Kawasan Wisata & Jumlah Pengunjung & Proporsi & Jumlah Obyek & Wilayah Kecamatan \\
\hline $\begin{array}{l}\text { Puncak dan } \\
\text { sekitarnya }\end{array}$ & 4.048 .132 & $54 \%$ & 29 & $\begin{array}{l}\text { Cisarua, Megamendung, Cijeruk, } \\
\text { Cigombong, Caringin, Ciawi }\end{array}$ \\
\hline $\begin{array}{l}\text { Sentul dan } \\
\text { sekitarnya }\end{array}$ & 1.676 .002 & $22 \%$ & 32 & $\begin{array}{l}\text { Sukaraja, Babakan Madang, Sukamakmur, } \\
\text { Cariu, Tanjungsari, Jonggol, Cileungsi, } \\
\text { Klapanunggal, Gunungputri, Citeureup, } \\
\text { Cibinong }\end{array}$ \\
\hline $\begin{array}{l}\text { Gunung Salak } \\
\text { Endah dan sekitarya }\end{array}$ & 1.198 .072 & $16 \%$ & 31 & $\begin{array}{l}\text { Pamijahan, Tenjolaya, Tamansari, } \\
\text { Cibungbulang, Ciampea,, Leuwiliang, } \\
\text { Leuwisadeng, Dramaga, Ciomas, Cigudeg, } \\
\text { Sukajaya, Nanggung,Jasinga }\end{array}$ \\
\hline $\begin{array}{l}\text { Gunung Sindur dan } \\
\text { sekitarnya }\end{array}$ & 617.003 & $8 \%$ & 3 & Parung, Gunung Sindur, Rumpin \\
\hline Total & 7.539 .209 & $100 \%$ & 93 & \\
\hline
\end{tabular}

Tabel 3. Sepuluh besar obyek wisata menurut jumlah pengunjung Tahun 2018

\begin{tabular}{lcccc}
\hline Objek Wisata & Nama Pengelola & Jenis & Kecamatan & Kunjungan Wisatawan \\
\hline Tmn Safari Indonesia & Yayasan T.Safari & Alam & Cisarua & 1.892 .120 \\
Taman Wisata Matahari (Swasta) & Swasta & Buatan & Megamendung & 1.195 .076 \\
Bakukung & BUMDES & Buatan & Leuwiliang & 775.495 \\
JungleLand & (SWASTA) & & Babakan Madang & 505.839 \\
Gunung Mas & PTPN VIII & Alam & Cisarua & 441.568 \\
Curug Cilember & KBM WBU Perhutani & Alam & Cisarua & 277.171 \\
Villa Khayangan & Swasta & & Cileungsi & 237.071 \\
TW Mekarsari & Swasta & Alam & Cileungsi & 221.368 \\
Water Kingdom & Swasta & & Cileungsi & 141.142 \\
Panorama Pabangbon & PERHUTANI DAN LMDH & Alam & Leuwiliang & 95.494 \\
\hline
\end{tabular}


Terdapat beberapa pendekatan dalam Analisis Citra Destinasi Wisata, yang utama adalah pendekatan perilaku rekreasi/recreation behavior Chon (1990) dan pendekatan perilaku konsumen/consumer behavior (Gartner, 1993). Pendekatan perilaku rekreasi adalah suatu proses yang meliputi (1) Primary Image Construction/aspek tendensi dan motivasional; (2) Anticipation - Decision to Travel /proses pertimbangan pengambilan keputusan, (3) Travel to site (4) Participation on site (5) Return Home dan (7) Recollection/evaluasi citra.

Ramseook-Munhurrun et al. (2015) menyatakan bahwa kepuasan wisatawan merupakan hal yang paling memengaruhi loyalitas wisatawan. Sejalan dengan itu $\mathrm{Wu}$ (2019) melengkapi pengetahuan bahwa loyalitas pengunjung dipengaruhi beberapa hal yakni citra destinasi, pengalaman perjalanan konsumen, dan kepuasan destinasi dalam konteks pariwisata. Ini diperkuat dengan Gursoy et al. (2014) dan Chi (2012) yang menunjukkan bahwa pengalaman sebelumnya memoderasi hubungan antara kepuasan wisatawan dan loyalitas destinasi. Sedangkan Kim (2018) menyatakan bahwa memorable tourism experiences (MTEs) paling menentukan kunjungan kembali.

Evaluasi citra destinasi dengan pendekatan perilaku konsumen dilakukan dengan menganalisis hubungan komponen kognitif, afektif dan konatif (Gartner, 1993; Baloglu dan McCleary, 1999; Pike dan Ryan, 2004). Komponen kognitif merupakan evaluasi atribut produk yang diketahui atau pemahaman produk dengan cara intelektual. Komponen afektif adalah citra yang berasal dari fakta (sensory). Sedangkan konatif adalah adalah citra destinasi yang analog dengan perilaku karena merupakan tindakan. Konatif merupakan hasil dari citra yang dikembangkan selama tahap kognitif dan dievaluasi selama tahap afektif (Gartner, 1993; Tasci, 2007). Evaluasi destinasi wisata Gartner dan Tasci tersebut perlu dilengkap dengan evaluasi Travel to site sesuai konsepsi Chon (1990).

Penelitian ini memadukan evaluasi citra destinasi wisata dengan pendekatan perilaku rekreasi (recreation behavior) sebagaimana Chon (1990) dan evaluasi wisata menurut Gartner (1993) dan Tasci (2007) yang membagi citra destinasi menjadi tiga elemen, yakni sense of place dan thinks to do serta total image berupa kepuasan.perilaku konsumen (consumer behavior).
Hubungan kepuasan dan loyalitas pengunjung ini juga merujuk pada konsep yang sudah luas diaplikasikan dalam penelitian kepuasan pelanggan seperti yang dilakukan Ismanto (2017). Berdasarkan uraian maka tujuan penelitian ini adalah Menganalisis hubungan struktural Travel Constraint dengan Citra Destinasi (sense of place, think to do) ekspresi pengunjung, kepuasan, terhadap Loyalitas Wisatawan.

\section{METODE PENELITIAN}

Penelitian dilakukan pada bulan Juli-Agustus 2019. Lokasi penelitian adalah (1) Ciputri Camping Ground, Desa Tapos 1 Kec. Tenjolaya; (2) Camping Ground Cipeteuy Desa Tapos 1 Kec. Tenjolaya; (3) Bogor Tenjolaya Park, Desa Tapos 1 Kec. Tenjolaya (4) Gunung Salak Endah, Desa Gunung Bunder 1 Kec. Pamijahan. Survey secara non probability sampling yakni dengan purposive sampling (Juanda, 2009) dengan 140 responden. Dalam Menganalisis hubungan struktural dipakai metode SEM-PLS (Hair et al. 2014, Kurniawan et al. 2016). Data diolah dengan software SmartPLS 2 untuk SEM-PLS.

Variabel Penelitian untuk model SEM - PLS terdapat delapan variabel latent, yakni X1 (Profil), X2 (Pra Travel), X3 (Travel Constrain), X4 (Sense of Place), X5 (Thinks To Do), X6 (Puas), X7 (Ekspresi), X8 (Loyalitas). X4 sampai X8 merupakan aspek citra destinasi. Masing-masing variabel latent memiliki variabel terukur sebagaimana Tabel 4.

Hipotesis penelitian ini berdasarkan Gartner (1993) yang menguraikan bahwa Citra Destinasi/Destination Image dibentuk oleh tiga komponen yang berbeda tetapi secara hierarki saling terkait: kognitif, afektif, dan konatif. Selanjutnya Tasci (2007) membagi aspek kognitif menjadi dua komponen yakni kesan tersensori terhadap lokasi wisata (setting/sense of place) dan aktivitas yang dapat dilakukan (activities/think to do) serta total image yang merupakan aspek konatif berupa kepuasan terhadap apa yang disensori dan dialami. Aspek loyalitas merupakan respon terhadap keseluruhan aspek sebelumnya. Untuk pengembangan pengetahuan maka dimasukkan pula dalam model : aspek profil pengunjung dan kendala perjalanan (travel constrain) serta aspek ekspresi dari suatu kepuasan. 
Tabel 4. Variabel Model SEM - PLS

\begin{tabular}{|c|c|c|c|}
\hline Variabel laten, Sumber & & Variabel Terukur & Pertanyaan/Diskripsi \\
\hline \multirow[t]{4}{*}{ X1 (Profil) } & (1) & X11 (Pendapatan) & Rp. \\
\hline & (2) & X12 (Pendidikan) & 1. SMP; 2. SMA; 3. D3; 4 SARJANA \\
\hline & (3) & X13 (Usia) & tahun \\
\hline & (4) & (X14) Perjalanan wisata & Frekuensi perjalanan wisata (kali/setahun) \\
\hline X2 (Pra Travel) (Chon, 1998) & $(5)$ & X21 (Khawatir) & Khawatir dengan Kondisi Tempat Yang Asing \\
\hline \multirow{4}{*}{$\begin{array}{l}\text { X3 (Travel Constrain) } \\
\text { (Chon, 1998) }\end{array}$} & (6) & X31 (Biaya) & Biaya Perjalanan Mahal \\
\hline & (7) & X32 (Bosan) & Mengalami Kebosanan Selama Perjalanan \\
\hline & (8) & X33 (Jarak) & $\begin{array}{l}\text { 1. dekat (sek.lokasi); 2. Sedang (Kab/Kota } \\
\text { Bogor) 3. Jauh (Luar Kabupaten) }\end{array}$ \\
\hline & $(9)$ & X34 (Waktu) & Waktu Tempuh Terasa Lama/Macet \\
\hline \multirow[t]{3}{*}{ X4 (Sense Of Place) (Tasci, 2007) } & $(10)$ & X41 (Air) & Air di sini sangat jernih dan menyegarkan \\
\hline & $(11)$ & X42 (Alam) & Pemandangan Alam di sini sangat indah \\
\hline & $(12)$ & X43 (Iklim) & Iklim di sini sejuk menyegarkan \\
\hline \multirow[t]{4}{*}{ X5 (Thinks To Do) (Tasci, 2007) } & (13) & X51 (Aktivitas Bersama) & Sangat cocok untuk acara bersama \\
\hline & (14) & X52 (Dkt Wisata lain) & Lokasi ini dekat dgn obyek wisata lainnya \\
\hline & $(15)$ & X53 (Relaksasi) & Sangat nyaman untuk relaksasi \\
\hline & (16) & X54 (Olah Raga) & Sangat cocok untuk jalan sehat/bersepeda/OR \\
\hline \multirow[t]{3}{*}{ X6 (Puas) (Tasci, 2007) } & $(17)$ & X61 (Menikmati) & lokasi yang menarik dan memuaskan \\
\hline & $(18)$ & X62 (Ramah) & Penduduk di sini ramah \\
\hline & (19) & X63 (Harga Wajar) & Tingkat Harga di Lokasi wajar \\
\hline \multirow[t]{2}{*}{ X7 (Ekspresi) (Garner, 1993) } & $(20)$ & X71 (Foto) & Upload foto dan Komentar Positif di Medsos \\
\hline & $(21)$ & X72 (Rekom) & Merekomendasikan Teman untuk berkunjung \\
\hline X8 (Loyalitas) (Garner, 1993) & $(22)$ & X81 (Kembali) & Pada kesempatan lain akan berkunjung kembali \\
\hline
\end{tabular}

Secara eksplisit hipotesis dalam model ini (Gambar 2) dinyatakan sebagai berikut, $\mathrm{H} 1$ : variabel laten profil pengunjung memengaruhi positif terhadap travel constrain,; H2 : variabel laten pra-travel memengaruhi positif terhadap travel constrain; H3: variabel latent travel constrain memiliki pengaruh negatif terhadap kepuasan, ekspresi dan loyalitas pengunjung; H4 : variabel latent setting/sense of place memiliki pengaruh positif terhadap think to do, kepuasan dan loyalitas pengunjung; H5 : variabel latent think to do memiliki pengaruh positif terhadap kepuasan dan loyalitas pengunjung; H6 : variabel latent kepuasan memiliki pengaruh positif terhadap ekspresi dan loyalitas pengunjung; $\mathrm{H} 7$ : variabel latent ekspresi memiliki pengaruh positif terhadap loyalitas pengunjung.

\section{HASIL}

\section{Profil Responden}

Terdapat 140 responden pengunjung lokasi wisata Responden pengunjung umumya laki-laki $(66,43 \%)$, usia kurang atau sampai 39 tahun $(89,29 \%)$. Pengunjung berasal dari sekitar lokasi wisata $(47,14 \%)$ dan dalam $\mathrm{Kab} /$ Kota Bogor (30,71\%). Ini berarti tipe pengunjung adalah wisatawan Day Trip from home/base - atau "excursionist". Status pekerjaannya terbanyak Pekerja $41,43 \%$. Umumnya berpendidikan SMA $(62,86)$ dan pendapatan kurang dari Rp. 2,5 juta/bulan (57,86\%). Profil responden selengkapnya pada Tabel 5.

\section{Evaluasi Model Pengukuran (Outer Model)}

Evaluasi outer model disebut pula dengan evaluasi model pengukuran dilakukan untuk menilai validitas dan reliabilitas model. Outer model dalam penelitian ini merupakan indikator refleksif bagi konstruk laten sehingga dievaluasi melalui validitas convergent dan discriminant (Chin, 1998). Selanjutnya variabel yang memiliki loading factor $>0,6$ dimasukkan dalam model (Tabel 6). Dari pengolahan data pertama maka model direduksi (sebagaimana dalam Gambar 4) untuk variabel terukur yang loading factor-nya yang kurang dari 0,6 dan tidak signifikan saat dilakukan bootstrapping, yakni perjwisata, biaya, olah raga, aktivitas bersama. 


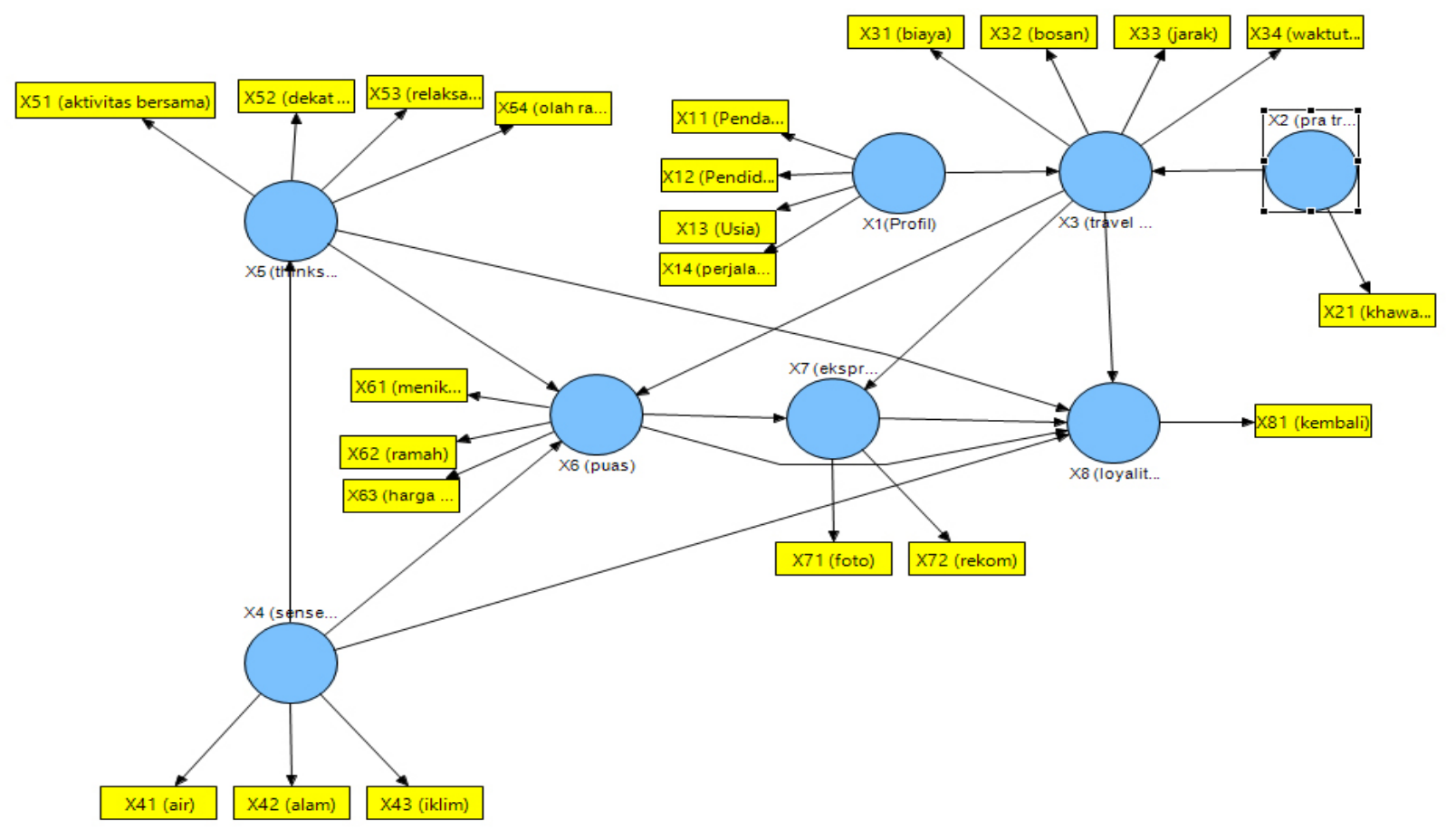

Gambar 2. Model Hipotesa SEM-PLS

Tabel 5. Profil Responden

\begin{tabular}{|c|c|c|c|c|c|c|c|c|c|c|c|}
\hline \multirow{3}{*}{ Variabel } & \multirow{3}{*}{ Notasi dan Penjelasan } & \multicolumn{8}{|c|}{ LOKASI } & \multirow{2}{*}{\multicolumn{2}{|c|}{$\begin{array}{c}\text { Total } \\
\mathrm{n}=140\end{array}$}} \\
\hline & & \multicolumn{2}{|c|}{$\begin{array}{l}\text { Ciputri } \\
(\mathrm{n}=34)\end{array}$} & \multicolumn{2}{|c|}{$\operatorname{GSE}(n=35)$} & \multicolumn{2}{|c|}{$\begin{array}{c}\text { Cipeteuy } \\
(\mathrm{n}=19)\end{array}$} & \multicolumn{2}{|c|}{ BTP $(n=52)$} & & \\
\hline & & JML & $\%$ & JML & $\%$ & JML & $\%$ & JML & $\%$ & JML & $\%$ \\
\hline \multirow[t]{2}{*}{ Gender } & 1.Laki-laki & 21 & 15,00 & 25 & 17,86 & 14 & 10,00 & 33 & 23,57 & 93 & 66,43 \\
\hline & 2.Perempuan & 13 & 9,29 & 10 & 7,14 & 5 & 3,57 & 19 & 13,57 & 47 & 33,57 \\
\hline \multirow{3}{*}{$\begin{array}{l}\text { Jarak asal } \\
\text { ke lokasi }\end{array}$} & 1.Dekat (Sekitar Lokasi) & 4 & 2,86 & 12 & 8,57 & 17 & 12,14 & 33 & 23,57 & 66 & 47,14 \\
\hline & 2.Sedang (Kab/Kota Bogor) & 18 & 12,86 & 7 & 5,00 & 2 & 1,43 & 16 & 11,43 & 43 & 30,71 \\
\hline & 3.Jauh (Luar Kabupaten) & 12 & 8,57 & 16 & 11,43 & 0 & 0,00 & 3 & 2,14 & 31 & 22,14 \\
\hline \multirow{2}{*}{$\begin{array}{l}\text { Status } \\
\text { pernikahan }\end{array}$} & 1. Single & 13 & 9,29 & 19 & 13,57 & 19 & 13,57 & 18 & 12,86 & 69 & 49,29 \\
\hline & 2. Menikah & 21 & 15,00 & 16 & 11,43 & 0 & 0,00 & 34 & 24,29 & 71 & 50,71 \\
\hline \multirow[t]{4}{*}{ Usia } & $1 .<20$ tahun & 4 & 2,86 & 9 & 6,43 & 14 & 10,00 & 12 & 8,57 & 39 & 27,86 \\
\hline & 2. 20-29 tahun & 16 & 11,43 & 16 & 11,43 & 5 & 3,57 & 7 & 5,00 & 44 & 31,43 \\
\hline & 3. 30-39 tahun & 12 & 8,57 & 6 & 4,29 & 0 & 0,00 & 24 & 17,14 & 42 & 30,00 \\
\hline & 4. $>40$ tahun & 2 & 1,43 & 4 & 2,86 & 0 & 0,00 & 9 & 6,43 & 15 & 10,71 \\
\hline \multirow[t]{5}{*}{ Pekerjaan } & 1. Pelajar & 4 & 2,86 & 1 & 0,71 & 6 & 4,29 & 27 & 19,29 & 38 & 27,14 \\
\hline & 2. Pekerja & 19 & 13,57 & 24 & 17,14 & 1 & 0,71 & 14 & 10,00 & 58 & 41,43 \\
\hline & 3. Belum bekerja & 1 & 0,71 & 8 & 5,71 & 12 & 8,57 & 0 & 0,00 & 21 & 15,00 \\
\hline & 5. Ibu rumah tangga & 6 & 4,29 & 0 & 0,00 & 0 & 0,00 & 3 & 2,14 & 9 & 6,43 \\
\hline & 6. Wiraswasta & 4 & 2,86 & 2 & 1,43 & 0 & 0,00 & 8 & 5,71 & 14 & 10,00 \\
\hline \multirow[t]{3}{*}{ Pendidikan } & 1. SMA & 16 & 11,43 & 25 & 17,86 & 19 & 13,57 & 28 & 20,00 & 88 & 62,86 \\
\hline & 2. Diploma & 6 & 4,29 & 2 & 1,43 & 0 & 0,00 & 14 & 10,00 & 22 & 15,71 \\
\hline & 3. Sarjana $(\mathrm{S} 1 / \mathrm{S} 2 / \mathrm{S} 3)$ & 12 & 8,57 & 8 & 5,71 & 0 & 0,00 & 10 & 7,14 & 30 & 21,43 \\
\hline \multirow[t]{3}{*}{ Pendapatan } & $1 .<2,5$ juta & 18 & 12,86 & 13 & 9,29 & 19 & 13,57 & 31 & 22,14 & 81 & 57,86 \\
\hline & 2. 2,5 s.d 5 Juta & 9 & 6,43 & 13 & 9,29 & 0 & 0,00 & 12 & 8,57 & 34 & 24,29 \\
\hline & 3. $>5,1$ & 7 & 5,00 & 9 & 6,43 & 0 & 0,00 & 9 & 6,43 & 25 & 17,86 \\
\hline
\end{tabular}




\section{Evaluasi Model Struktural (Inner Model)}

Beberapa uji validitas model (Tabel 6) menyatakan bahwa beberapa parameter model memberikan nilai diatas standar kriteria, yakni AVE $>0,5$; Outer Loading factor $>0,5$; Composite Reliability $>0,6$. Selanjutnya, melihat nilai signifikansi T-statistik dengan metode boostrapping (Tabel 7). Koefisien Jalur yang signifikan $(>1,96$ untuk taraf nyata 0,05$)$ adalah pada hubungan antar konstruk (variabel laten). Struktur hubungan, nilai outer loading dan path coefficient dapat dilihat pada Gambar 4.

Konstrak X3 (travel constrain) diukur dari bosan selama perjalanan, waktu tempuh lama dan jarak. Konstrak X3 dipengaruhi oleh konstrak X1 (profil) dan X2. Konstrak X1 diukur berdasarkan pendidikan, pendapatan dan usia. Konstrak X2 (pra travel) diukur berdasarkan tingkat perasaan khawatir terhadap kondisi lokasi yang dituju.
Aspek X5 (things to do) tidak menjadi daya saing lokasi ini karena memberikan koefisien jalur yang negatif terhadap konstrak X8 (loyalitas). Hal dikarenakan beberapa hal, salah satunya adalah belum adanya variasi kegiatan yang dapat dilakukan di lokasi wisata yang memungkinkan keterlibatan wisatawan. Kegiatan masyarakat yang berbasis budidaya pertanian yang harusnya dapat menjadi daya tarik belum terkait dengan core attractor. Petani dan kelompok masyarakat yang terlibat dalam kegiatan wisata tidak ada jalinan kerjasama yang sinergis. Sementara ini Kelompok masyarakat (yang mendapatkan ijin pengelolaan jasa lingkungan di Taman Nasional : Ciputri-Cipeteuy dan Gunung Salak Endah) nampaknya sudah dalam kondisi nyaman dengan "hanya" mengandalkan pendapatan yang dipungut dari wisatawan (tiket masuk dan parkir).

Tabel 6. Hasil SEM-PLS

\begin{tabular}{|c|c|c|c|c|c|c|c|c|}
\hline \multicolumn{7}{|c|}{ Inner Model Overview } & \multicolumn{2}{|c|}{ Outer Model Overview } \\
\hline Variabel laten & AVE & $\begin{array}{l}\text { Composite } \\
\text { Reliability }\end{array}$ & $\begin{array}{c}\mathrm{R} \\
\text { Square }\end{array}$ & $\begin{array}{c}\text { Cronbachs } \\
\text { Alpha }\end{array}$ & Communality & $\begin{array}{l}\text { Redun- } \\
\text { dancy }\end{array}$ & $\begin{array}{l}\text { Variabel } \\
\text { terukur }\end{array}$ & $\begin{array}{l}\text { Loading } \\
\text { Factor }\end{array}$ \\
\hline \multirow[t]{3}{*}{ X1(Profil) } & 0,6217 & 0,8304 & 0,0000 & 0,6932 & 0,6217 & 0,0000 & $\begin{array}{l}\text { X11 } \\
\text { (Pendapatan) }\end{array}$ & 0,8235 \\
\hline & & & & & & & $\begin{array}{l}\text { X12 } \\
\text { (Pendidikan) }\end{array}$ & 0,6956 \\
\hline & & & & & & & X13 (Usia) & 0,8384 \\
\hline X2 (pra travel) & 1 & 1 & 0,0000 & 1 & 1 & 0,0000 & X21 (khawatir) & 1,0000 \\
\hline \multirow[t]{3}{*}{$\begin{array}{l}\text { X3 (travel } \\
\text { constrain) }\end{array}$} & 0,7445 & 0,8970 & 0,1712 & 0,8292 & 0,7445 & 0,0775 & X32 (bosan) & 0,8437 \\
\hline & & & & & & & X33 (jarak) & 0,8035 \\
\hline & & & & & & & $\begin{array}{l}\text { X34 } \\
\text { (waktutempuh) }\end{array}$ & 0,9360 \\
\hline \multirow[t]{3}{*}{$\begin{array}{l}\text { X4 (sense of } \\
\text { place) }\end{array}$} & 0,7405 & 0,8953 & 0,0000 & 0,8259 & 0,7405 & 0,0000 & X41 (air) & 0,8745 \\
\hline & & & & & & & X42 (alam) & 0,8188 \\
\hline & & & & & & & X43 (iklim) & 0,8866 \\
\hline \multirow[t]{3}{*}{ X5 (thinks to do) } & 0,7176 & 0,8816 & 0,5937 & 0,8000 & 0,7176 & 0,4138 & $\begin{array}{l}\text { X51 (akt- } \\
\text { bersama) }\end{array}$ & 0,9219 \\
\hline & & & & & & & $\begin{array}{l}\text { X52 (dkt } \\
\text { wisatalain) }\end{array}$ & 0,6556 \\
\hline & & & & & & & X53 (relaksasi) & 0,9344 \\
\hline \multirow[t]{2}{*}{ X6 (puas) } & 0,7113 & 0,8311 & 0,5872 & 0,5975 & 0,7113 & 0,2482 & $\begin{array}{l}\text { X61 } \\
\text { (menikmati) }\end{array}$ & 0,8768 \\
\hline & & & & & & & X62 (ramah) & 0,8085 \\
\hline \multirow[t]{2}{*}{ X7 (ekspresi) } & 0,7028 & 0,8232 & 0,2217 & 0,6118 & 0,7028 & 0,0836 & X71 (foto) & 0,7261 \\
\hline & & & & & & & X72 (rekom) & 0,9372 \\
\hline X8 (loyalitas) & 1 & 1 & 0,5322 & 1 & 1 & 0,3766 & X81 (kembali) & 1,0000 \\
\hline
\end{tabular}


Tabel 7. Path coefficient dan signifikansinya

\begin{tabular}{lcc}
\multicolumn{1}{c}{ Path } & Path Coefficient & T Statistics $(\mid \mathrm{O} /$ \\
STERR $\mid)$
\end{tabular}

$*=$ nyata $\mathrm{p}(0,05) \quad * *=$ nyata $\mathrm{p}(0,01) \quad \mathrm{NS}=$ tidak nyata

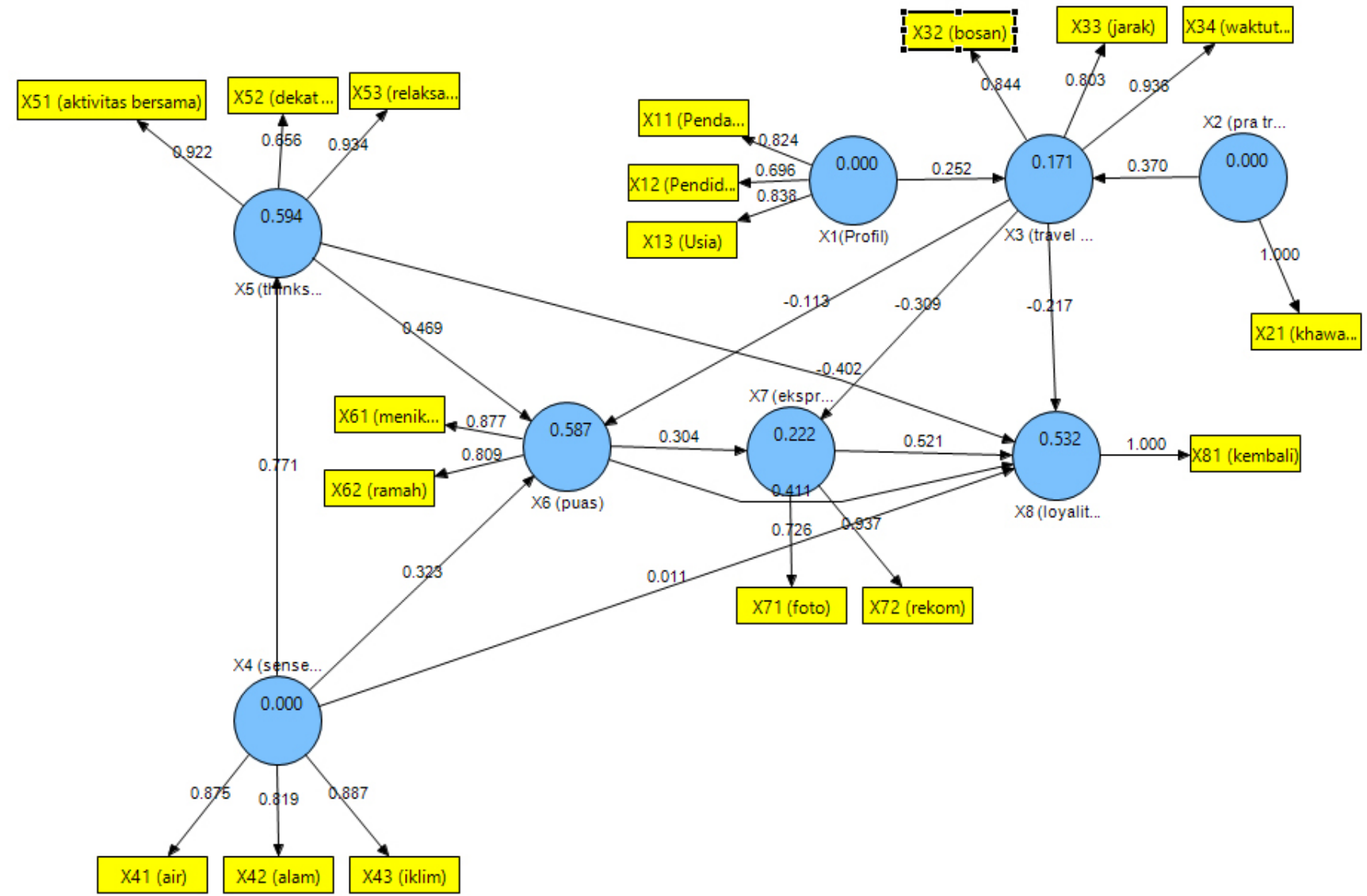

Gambar 4. Struktur hubungan, nilai outer loading factor dan path coeffcient (model SEM-PLS setelah reduksi) 
Konstrak X3 memengaruhi secara negatif konstrak: X6 (-0,113), X7 (-0,309), X8 (-0,217). Artinya, dengan adanya kendala perjalanan maka akan menghambat kepuasan, ekspresi positif dan loyalitas pengunjung.

Konstrak ekspresi (X7) yang terlihat dari tindakan mengupload foto-foto selamaberwisata dan memberikan rekomendasi pada teman sangat dipengaruhi oleh konstrak kepuasan (X6). Dan konstrak X7 ini sangat menentukan konstrak $\mathrm{X} 8$, artinya jika wisatawan melakukan tindakan mengekspresikan kepuasan dengan mengupload foto dan memberikan rekomendasi maka peluang untuk berkunjung kembali semakin besar.

Selanjutnya, dilakukan Analisis jalur (langsung dan tidak langsung) yang hasilnya sebagaimana Tabel 8. Secara struktural adanya konstrak X3 (travel constrain) akan mengakibatkan berkurangnya peluang X8 (loyalitas) yang diukur dengan minat kunjungan kembali dengan besaran koefisien jalur - 0,443, nilai negatif ini lebih besar dari pengaruh positif secara struktural dari X4 (sense of place) yang hanya 0,390.

Hubungan X4 (sense of place) dan X8 (loyalitas) memberikan nilai koefisin jalur yang tidak nyata. Hal berarti lokasi penelitian tidak bisa hanya mengandalkan konstrak X4 yang dibentuk dari kondisi alamiah (kejernihan air, kesegaran iklim dan keindahan lama) dalam menarik wisatawan untuk kembali lagi.
Lokasi yang lebih mengandalkan kondisi alamiah dan memiliki kendala perjalanan memiliki daya saing yang rendah, yakni ditunjukkan dengan minat wisatawan untuk datang kembali. Terkait dengan besarnya pengaruh konstrak X3 terhadap konstrak X8, dapat dijelaskan bahwa loyalitas wisatawan merupakan aspek konatif sebagaimana menurut Gartner (1993) atau tahap recollection/tindakan atas dasar pengalaman sebelumnya (Chon 1990) ini sangat ditentukan faktor travel to site dalam hal ini yang diukur adalah persepsi terhadap kendala/ketidaknyamanan yang dirasakan selama perjalanan.

Tidak idealnya jalur menuju lokasi wisata dapat digambarkan bahwa setelah melewati jalan propinsi (ruas Bogor-Jasinga), rute perjalanan menuju lokasi wisata melalui jalan yang memiliki lebar yang hanya mampu dilalui dua mobil tanpa ada bahu jalan. Dan melewati dua pasar desa yang ramai dan macet. Suasana jalan tidak selayaknya jalur wisata, namun melewati pemukiman penduduk yang cukup padat dan kurang memberikan impresi keindahan pemandangan. Menuju lokasi wisata tidak terdapat jalur yang merupakan koridor wisata yang memberikan citra keindahan pegunungan yang segar.

\section{Implikasi Manajerial}

Perlunya mengintegrasikan percepatan pembangunan infrastruktur jalan dan realisasi investasi wisata agar kendala perjalanan menuju lokasi dapat teratasi. Jaringan jalan yang dibangun merupakan koridor/ jalur wisata yang tertata rapi selain fungsi utama memperlancar transportasi menuju lokasi wisata.

Tabel 8. Jumlah path coefficient menurut jalurnya

\begin{tabular}{llc}
\hline Jalur Langsung & Seluruh jalur & Koefisien jalur \\
\hline $\mathrm{X}$ (travel constrain $) \rightarrow \mathrm{X} 8$ (loyalitas) & $\mathrm{X} 3 \rightarrow \mathrm{X} 8$ & $-0,2174$ \\
& {$[\mathrm{X} 3 \rightarrow \mathrm{X} 7] \times[\mathrm{X} 7 \rightarrow \mathrm{X} 8]$} & $-0,16$ \\
& {$[\mathrm{X} 4 \rightarrow \mathrm{X} 6] \times[\mathrm{X} 6 \rightarrow \mathrm{X} 8]$} & $-0,05$ \\
& {$[\mathrm{X} 3 \rightarrow \mathrm{X} 6] \times[\mathrm{X} 6 \rightarrow \mathrm{X} 7] \times[\mathrm{X} 7 \rightarrow \mathrm{X} 8]$} & $-0,02$ \\
& Jumlah & $-0,443$ \\
$\mathrm{X} 4($ Sense of Place) $\rightarrow \mathrm{X} 8$ (loyalitas) & {$[\mathrm{X} 4 \rightarrow \mathrm{X} 6] \times[\mathrm{X} 6 \rightarrow \mathrm{X} 8]$} & 0,133 \\
& {$[\mathrm{X} 4 \rightarrow \mathrm{X} 6] \times[\mathrm{X} 6 \rightarrow \mathrm{X} 7] \times[\mathrm{X} 7 \rightarrow \mathrm{X} 8]$} & 0,05 \\
& {$[\mathrm{X} 4 \rightarrow \mathrm{X} 5] \times[\mathrm{X} 5 \rightarrow \mathrm{X} 6] \times[\mathrm{X} 6 \rightarrow \mathrm{X} 8]$} & 0,15 \\
& {$[\mathrm{X} 4 \rightarrow \mathrm{X} 5] \times[\mathrm{X} 5 \rightarrow \mathrm{X} 6] \times[\mathrm{X} 6 \rightarrow \mathrm{X} 7] \mathrm{x}[\mathrm{X} 7 \rightarrow \mathrm{X} 8]$} & 0,06 \\
& $\mathrm{Jumlah}$ & 0,390 \\
$\mathrm{X} 5($ Thinks to Do $\rightarrow \mathrm{X} 8$ (loyalitas) & {$[\mathrm{X} 5 \rightarrow \mathrm{X} 8]$} & $-0,4025$ \\
& {$[\mathrm{X} 5 \rightarrow \mathrm{X} 6] \times[\mathrm{X} 6 \rightarrow \mathrm{X} 8]$} & 0,193 \\
& Jumlah & $-0,21$ \\
\hline
\end{tabular}




\section{KESIMPULAN DAN SARAN}

\section{Kesimpulan}

Konstrak X3 (travel constrain atau kendala perjalanan) berpengaruh negatif secara nyata $(-0,443)$ dalam memengaruhi konstrak X6 (kepuasan), X7 (ekspresi) dan X8 (loyalitas pengunjung) yang direfleksikan dengan minat kunjungan kembali. nilai negatif ini lebih besar dari pengaruh positif secara struktural dari X4 (sense of place) yang hanya 0,390 . Selain itu dapat disimpulkan bahwa lokasi yang hanya mengandalkan kondisi alamiah tidak signifikan pengaruhnya terhadap minat wisatawan untuk melakukan kunjungan kembali. Citra destinasi berupa sense of place dan thinks to do baru dapat memengaruhi minat kunjungan kembali jika pengunjung merasakan kepuasan serta melakukan tindakan ekspresi yang positif.

\section{Saran}

Perlu dilakukan dengan peningkatan core attraction yang lebih menarik dan inovatif serta sesuai keinginan pengunjung, agar calon pengunjung yang dekat, yakni di wilayah Kabupaten Bogor tetap tertarik datang ke lokasi wisata tersebut. Perlu dilakukan Penelitian yang lebih bersifat makro terkait dengan perencanaan Kawasan wisata Halimun Salak terkait dengan pengembangan wilayah Kabupaten Baru di wilayah Bogor bagian Barat, terutama aspek aksesibiltasnya dan infrastruktur lainnya

\section{DAFTAR PUSTAKA}

Baloglu S, Ken W, McCleary. 1999. A model of destination image formation. Annals of Tourism Research 26(4):868-897. https://doi. org/10.1016/S0160-7383(99)00030-4

[BPS] Badan Pusat Statistik Kab. Bogor. 2017. Statistik Daerah Kabupaten Bogor Tahun 2017. Bogor: BPS.

Campón-Cerro AM, Hernández-Mogollón JM, Alves H. 2017. Sustainable improvement of competitiveness in rural tourism destinations: The quest for tourist loyalty in Spain. Journal of Destination Marketing \& Management 6(3):252-266. https://doi.org/10.1016/j. jdmm.2016.04.005

Chi CGQ. 2012. An examination of destination loyalty: Differences between first-time and repeat visitors. Journal of Hospitality \& Tourism Research 36(1):3-24.https://doi. org/10.1177/1096348010382235

Chin WW. 1998. The Partial Least Squares Approach to Structural Equation Modeling. Mahwah: Lawrence Erlbaum Associates.

Chon KS. 1990. The role of destination image in tourism: A review and discussion. The Tourist Review (2): 2-9. https://doi.org/10.1108/eb058040

Gartner W. 1993. Image formation process. Communication and Channel Systems in Tourism Marketing 2(2-3):191-215. https://doi. org/10.1300/J073v02n02_12

Gursoy D, Chen JS, Chi CG. 2014. Theoretical examination of destination loyalty formation. International Journal of Contemporary Hospitality Management 26(5): 809-827. https:// doi.org/10.1108/IJCHM-12-2013-0539

Hair, Joseph F, Marko S, Lucas H, Volker G, Kuppelwieser. 2014. Partial least squares structural equation modeling PLS-SEM: An emerging tool in business research. European Business Review 26(2):106-121.https://doi. org/10.1108/EBR-10-2013-0128

Ionela GP, Bârsan MCb, Lia-DoricaD. 2015.Advantages and limits for tourism development in rural area: Case study Ampoi and MureúValleys. Procedia Economics and Finance (32):1050-1059. https:// doi.org/10.1016/S2212-5671(15)01567-1

Ismanto H. 2017. Kepuasan konsumen dan kinerja keuangan UKM di Kabupaten Jepara. Jurnal Aplikasi Manajemen dan Bisnis 4(3):377-386. https://doi.org/10.17358/jabm.4.3.377

Jepson D, Sharpley R. 2015. More than sense of place? Exploring the emotional dimension of rural tourism experiences. Journal of Sustainable Tourism 23(8):1-22. https://doi.org/10.1080/096 69582.2014 .953543

Juanda B. 2009. Metodologi Penelitian Ekonomi dan Bisnis. Bogor: IPB Press.

Kim JH. 2018. The impact of memorable tourism experiences on loyalty behaviors: The mediating effects of destination image and satisfaction. Journal of Travel Research 57(7):856-870. https://doi.org/10.1177/0047287517721369

Hendra K, Satria A, Suprayitno G. 2016. Perancangan strategi bauran pemasaran untuk meningkatkan kepuasan dan loyalitas nasabah pembiayaan umrah. Jurnal Aplikasi Manajemen dan Bisnis 2(2):32-42.

Morag M, Hall D. 2005. Rural tourism as sustainable 
business: key themes and issues. Rural Tourism and Sustainable Business 2005: 3-14. https:// doi.org/10.21832/9781845410131-004

Pike S, Ryan C. 2004. Destination positioning analysis through a comparison of cognitive, affective, and conative perceptions. Journal of Travel Research 42(4):333-342. https://doi. org/10.1177/0047287504263029

Ramseook-Munhurrun P, Seebaluck VN, Naidoo P. 2015. Examining the structural relationships of destination image, perceived value, tourist satisfaction and loyalty: case of Mauritius. Procedia-Social and Behavioral Sciences 175:252-259.https://doi.org/10.1016/j. sbspro.2015.01.1198

Schubert D. 2006. Active Regions-Shaping Rural Futures: A Model for New Rural Development in Germany. Paris: OECD Publishing.

Sharpley R, Pearce T. 2007. Tourism, marketing and sustainable development in the English national parks: The role of national park authorities. Journal of Sustainable Tourism 15(5):557-573. https://doi.org/10.2167/jost613.0

Tasci ADA. 2007. Assessment of factors influencing destination image using a multiple regression model. Tourism Review 62(2):23-30. https://doi. org/10.1108/16605370780000311 